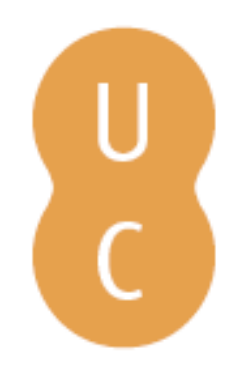

\title{
nommalina
}

\section{Making Bologna really work!}
Autor(es):
Sterken, Elmer
Publicado por: Imprensa da Universidade de Coimbra
URL persistente:
URI:http://hdl.handle.net/10316.2/46348
DOI:
DOI:https://doi.org/10.14195/978-989-26-1620-9_9

Accessed : $\quad$ 26-Apr-2023 13:01:15

A navegação consulta e descarregamento dos títulos inseridos nas Bibliotecas Digitais UC Digitalis, UC Pombalina e UC Impactum, pressupõem a aceitação plena e sem reservas dos Termos e Condições de Uso destas Bibliotecas Digitais, disponíveis em https://digitalis.uc.pt/pt-pt/termos.

Conforme exposto nos referidos Termos e Condições de Uso, o descarregamento de títulos de acesso restrito requer uma licença válida de autorização devendo o utilizador aceder ao(s) documento(s) a partir de um endereço de IP da instituição detentora da supramencionada licença.

Ao utilizador é apenas permitido o descarregamento para uso pessoal, pelo que o emprego do(s) título(s) descarregado(s) para outro fim, designadamente comercial, carece de autorização do respetivo autor ou editor da obra.

Na medida em que todas as obras da UC Digitalis se encontram protegidas pelo Código do Direito de Autor e Direitos Conexos e demais legislação aplicável, toda a cópia, parcial ou total, deste documento, nos casos em que é legalmente admitida, deverá conter ou fazer-se acompanhar por este aviso.

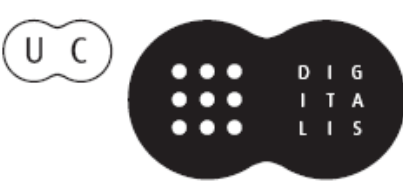


Cristina Pinto Albuquerque Ana Maria Seixas

Albertina Lima Oliveira

António Gomes Ferreira

Maria Paula Paixão

Rui Paquete Paixão COORDS

\section{HIGHER}

EDUCATION

AFTER

BOLOGNA

Challenges and Perspectives 


\title{
CHAPTER 9
}

\section{MAKING BOLOGNA REALLY WORK!}

\author{
Elmer Sterken \\ University of Groningen (Netherlands) \\ E-mail: e.sterken包rug.nl
}

This chapter contains an optimistic view on the Bologna process. Academic development benefits from cooperation and collaboration. Europe has an ideal history to stimulate international academic cooperation. Universities make progress in internationalization: they move from adjusting the language of instruction to spreading their reputation and to optimizing internationalization at home. In education European universities should work on inclusion - making all students feel welcome in their system - and activation - getting students in an active mode in the educational process. For instance project-based education can both activate students in learning and bring real-life cases into academic training. A strong and collaborative academic Europe benefits all. 


\section{Introduction}

On June $19^{\text {th }} 1999$ the Bologna Declaration has been signed. Since 1999 higher education in Europe has developed substantially in terms of quality. Students have become more mobile, universities have opened and standardized their programs and the European Higher Education Area (EHEA) has made serious contributions to welfare. Despite economic and political struggles in the last couple of years the goals of European higher education policy remain the same as in 1999. Cooperation and collaboration continue to be important and welfare-improving objectives for European universities and corresponding nation states.

In this chapter I will strongly support the Bologna process. The main argument is that cooperation and collaboration in higher education bring welfare. I first review the post-Bologna experiences. The main achievements and drawbacks are very well known and can so be dealt with in brief. Next I will sketch the future of internationalization of European higher education. Two current developments affect higher education to a large extent. First, the international labor markets are in a continuous change and show an increasing volatility of jobs and job duration. Secondly, the development of ICT in education changes academic training at a rapid pace. Nowadays, we are able to share information quickly and in an efficient way. Students can get access to knowledge no matter where they live or work. This allows that students can benefit at the maximum of available information and need more training to access information than to remember details. The availability of ICT also allows for better quality of contact hours between lecturers and students. Instead of 'consuming' information alone, students can nowadays interact better with their lecturers. So, 
ICT allows for new forms of learning. I see two major lines. First, distance learning opens news ways of learning. Students around the world who do not have access to higher education now can follow basic and even advanced courses offered by top-quality universities. And secondly, ICT also makes campus education more vivid. The main focus of higher education at the institutional campus level should be twofold: (1) inclusion of all students, domestic and foreign, into the local system, and (2) activation of students in the classroom.

How did we get at this previously mentioned high-level stage of educational development in Europe? The signing of the Bologna Declaration in 1999 has increased the speed of internationalization across Europe. Although a simple counterfactual is not an option, we should ask ourselves whether we would have reached the current level of quality of higher education and welfare without the help of the Bologna process. My direct answer would be: without Bologna we would still have a more regional or national approach to education. But before coming to conclusions, let's review how we came to 2016. I start with a view from 1614, the foundation year of the University of Groningen and will illustrate how international education was at that time. Then I shortly discuss the formation of European nation states in different times of war turmoil and finally how we got to the Bologna declaration.

\section{The old days}

On August 23rd 1614 the local crowd cheered when six professors left the Martini Church in Groningen, a northern city in the Netherlands, at that time at war with Spain. The six professors attented the inaugural session of the university and 
one of them, Ubbo Emmius, became the first Rector Magnificus. Emmius was a German professor, born in Greetsiel, Ost-Frisia, in Germany, trained in Rostock and had taken experience in travel to universities in European countries, like France, Switzerland and Italy. Emmius was supervised during his studies by the famous Professor David Chytraeus in Rostock, followed his classes in the Michaeliskloster (now the University Library of the University of Rostock) and took over the Humanist ideas as put forward by King Alfonso of Naples in the fifteenth century. Coming to Groningen Ubbo Emmius wrote an 'Eternal Edict' stating the humanist ideas in the University of Groningen setting.

The University of Groningen became a truly international university in the seventeenth century with 40 percent of its students being foreign, although it should be admitted that students coming from today's southern Dutch provinces Brabant and Limburg were considerered to be foreigners. It was popular as a student in those days to travel across Europe to those places and institutions where famous professors were lecturing. Allin-all no wonder that the crowd of Groningen cheered at the inaugural sessions. The city was in an economic upsurge and the Hanze Union and - linkages (for instance with again Rostock) gave welfare to the region. Due to the economic boom increased the need for training of medical doctors, lawyers and referents. New intellectual capital was needed and appreciated.

A few decades before, in 1575, William of Orange founded a university at Leiden. Although this was still at the beginning of the war with Spain, it preluded at the rise of the Netherlands as a powerful state. The Netherlands became a world economic power in the seventeenth century and although European unification was still far out of sight, the general believe was that trade, knowledge and welfare were related. Each of the seven Dutch provinces (in those days called states) was allowed to start a 
university (five actually did so) and intellectual climate developed quickly. The average income per capita in the Netherlands became the highest of the world in the seventeenth century. Scientic inventions became common and an academic tradition started.

Soon after Leiden, a university started in Franeker, and more would follow after Groningen in Harderwijk, Utrecht and Amsterdam. The lesson to be learned from this seventeenth century experience in the Netherlands had been learned before in many European countries, but most prominently in France, Italy, Portugal, Spain and the United Kingdom. There is a strong correlation between economic and intellectual welfare, between academic development, 'openness' and mobility, between academic autonomy and scientific productivity. Academic success also seems to trigger internationalisation.

The way we look nowadays at collaboration and exchange goes back to the work of the famous economist David Ricardo (17721823). Ricardo showed that trade (or exchange of ideas) leads to higher welfare. The main reason is that each individual agent (or researcher or country) has a relative comparative advantage. In a team of researchers or a pool of students collaboration and exchange therefore lead to a higher social welfare. As long as the costs of mobility or collaboration don't exceed these alleged benefits, cooperation and collaboration in higer education pay off. So this holds within the European union: the basis of the Bologna treaty.

The prosperity European countries were able to achieve was decreased during the centuries of political turmoil and wars during the 18th, 19th and first half of the 20th century. In those days more focus was put on the formation of nation states and the protection of national heritage and domestic economic progress. One could argue that may European universities also suffered from religious battles. The result was anyhow that 
scientific collaboration was at a relatively low intensity, as was the international student mobility. Ending with the Second World War in the 1950s European countries felt again the need to collaborate in the newly-formed European Union. As we know by now, this was good news for academic development. As stated before, in 1999 the Bologna Declaration was signed.

\section{2. 'Bologna' in a nutshell}

Before turning to an evaluation of the Bologna-process it is natural to give a quick review of the 'Bologna'-achievements. With the unification of different parts of Europe on the way, it is quite natural to start thinking about creating a European Higher Education Area (EHEA). R\&D spillovers are abundant and one wants to avoid that new inventions stop at the border. Intellectual cooperation is therefore seen as a necessity. It was considered to be a public task to bring knowledge to as many European citizens as possible: setting up the European Higher Education Area (EHEA) is still believed to help all Europeans.

Of course it is relevant in this process that mobility of academics increases. An increase of mobility of staff and students can lead and/or help/support to:
a) getting a uniform credit transfer system (European Credit Transfer and Accumulation System, ECTS),
b) creating automated transfer of credits between institutions (the Groningen Declaration, (2012),
c) creating of a diploma supplement stating accomplishments,
d) introducing a uniform quality control process,
e) adapting uniform learning outcomes,
f) implementing double- and joint degrees, 
g) increasing general cooperation between universities,

h) elaborating the ERASMUS-program,

i) implementing fully the Bachelor-Master-Doctoratestructure (3-cycles).

Besides setting up the EHEA and creating the instruments to speed up mobility of staff and students, additional goals of the Bologna process were formulated after 1999: the pursuit of a "social dimension"; support for lifetime learning; recognition of the global impact of the Bologna process.

Moreover and finally, embracement of important additional stakeholders in Europe was proposed: European University Association; European Students' Union; European Association for Quality Assurance in Higher Education; Business Europe.

The European Higher Education Area has indeed developed successfully. The number of included countries has increased from 29 at the start to 47 members now. Moreover, the eight European Frame Programmes have both stimulated mobility of individual excellence (European Research Council) as well as network formation (via for instance Twinning and Teaming) and there are many more success stories.

As we consider the educational implementation of 'Bologna' there are some serious drawbacks though. First, the completion of national outcomes frameworks is troublesome. The diploma supplement is provided, but acceptance and understanding by employers remains a challenge. Secondly, wide implementation of the three-year bachelor, which requires an efficient curriculum, has made it more challenging for students to consider study abroad. Thirdly, there is a limited convergence of national quality assurance policies: this leads to difficulties in implementing double and joint degrees. Moreover, availability of online descriptions of programmes is still a problem at many institutions. 
Next, conversion of results using grading tables and automated transfer is lacking to a large extent. So, there are still many practical issues to be solved.

There are also more serious macro-concerns. Political support for European convergence has decreased in the last years. The economic crisis of 2008 / 2009 has led to a divergence of interests between various European countries and nationalism is a serious threat to internationalization. And finally, the speed of convergence of the accession countries (new-member states) is rather low. These macro-concerns lead to a lower willingness to invest in European harmonization.

Forming the European Higher Education Area needs serious seed money and the economic and financial crisis has made resources scarce. Again, the political will to offset national interests to the favor of international collaboration seems to have lost power. Therefore it remains a big challenge to illustrate the large advantages of international cooperation and collaboration. I will do so hereafter and present some views on modern ways of internationalization of universities.

\subsection{Internationalization}

Why would a university restrict its recruitment to home country or home region students and staff? Why would talented people only live in the direct vicinity of the institution? Why is it a requirement that both staff an students come from the local culture and speak the native language? Is this fair and does it lead to high local welfare? The way I pose these questions is answering them: it is not.

I am not arguing that universities do not have local responsibilities. Societal impact in the region is a major 'reason 
to exist', since local tax-payers are most likely to be important fundraisers of the university. But a university can be the 'entrance to the world' for the local community, while research in the region can be considered to be the product of a local living lab. Universities can be considered to be intermediairies for the region to the world.

In this chapter I am not paying too much attention to distance learning and the use of Massive Open Online Courses (MOOCs), but give a stronger emphasis on campus education. Major universities run both operations, distance and campus education, but for sake of simplicity I focus on the campus model.

\section{Internationalisation 3.0}

Starting from the observation that talented people can live all around the world, most universities started their internationalization process by adopting the lingua franca of science and/or attracting foreign students. In general we call this episode of internationalization phase 1.0. Universities in countries wherein the native language did not have an appeal to incoming students changed their language of instruction to English (like in the case of Dutch universities). Others opened their doors to talented students from abroad. The number of international students increased during phase 1.0: either full degree students or students on an exchange term.

The educational model however did not change too much. Apart from the language of instruction (books, articles, lectures, lecture notes), hardly any attention was given to inter-cultural differences and/or backgrounds of students. To some students the cultural shock of studying abroad could be interesting, to others threatening. In class lecturers did not consider the heterogeneous background of students to be an issue. 
On the other hand universities understood that apart from inviting foreign students to become their own students, internationalization phase $1.0 \mathrm{did}$ not contribute as such to a better reputation of the institution as such. Each institution strives actively for increasing its academic reputation. Through a better reputation international students will become more eager to come and study. Without a good information market of 'university quality' most universities were/are forced to use the international rankings, such as the Academic Ranking of World Universities (ARWU), the Quacquarelli Symonds World University Rankings (QS) and the Times Higher Education Supplement World University Rankings (THES), to signal quality to outsiders. Partly these rankings are based on surveys that try to measure reputation, but they only can cover partially the full academic standing of participating universities. The concern for increasing international reputation is a characteristic of internationalization phase 2.0.

Spreading the reputation of the institution is getting larger importance in a communication world. It is quite easy for students to access information concerning the quality of a university. The traditional flaw though is that the quality rankings are largely determined by research performance and so much by educational quality. So in many cases the next step of internationalization policy, say phase 3.0, is the adjustment of the educational space at home.

Before describing how the adjustment of the international educational space at home can be done a few words about changes in the environment that have speeded up this process. First, international labor markets have changed and are changing. Today's alumni students need to have more skills and competencies than in the past. They should be able to use their knowledge and level of thinking in a more rapidly changing environment, where 
job duration has become shorter and shorter. Collaboration and 'project' skills have become more relevant and creativity in the use of academic knowledge has become more prominent than before. The second change is the use of ICT. ICT has speeded up professional life. It has also changed the set of available teaching and learning tools. We can use videos, voting systems, annotation techniques, etc. in education, which has changed or can change the nature of how we teach and/or learn. This phenomenon as such is not new. Like at many other universities lectures used to be very long centuries ago, sometimes up to five hours. And in many universities the introduction of a book instead of using teaching notes has also been under discussion! So, technological progress in education is of all times. But let's turn back to the adjustment of campus education for international students in current days. I am convinced that for a young student the model of moving to a university town, setting up an independent and responsible life as a citizen and becoming an academic is still attractive. This applies to domestic and foreign students.

\subsection{Inclusion}

For a campus university it is of extreme importance that students feel at home and included in the wide system of the campus. This applies to the domestic students, but even more to the incoming ones. Inclusion applies to both the academic and the non-curricular environment. Language and culture play important roles in this process.

So the first adjustment to the model of a home campus is the creation of the Multilingual and Multicultural Learning Space (MMLS). In a few words this implies that any student, either 
home-based or foreign, should feel welcome in all the institutions that the university offers. That starts with an introduction of students into the educational model, into the cultural values, into the 'local habits' and so on. It is no big deal that a student needs to pass cultural barriers as long as it is known and explained. It is no big deal that many examples in class are taken from the region as long as it is made clear in advance. It is no serious issue that the local grading system differs, as long as it is made clear to guest students. In general universities need to bring a lot more effort in preparing students before the program starts. The final goal again is that all students feel included and embedded in the local academic scene.

\subsection{Activation}

The second adjustment is the activation of students. By activation I mean students being active during contact hours with the lecturers. The days that courses were taught by giving large-scale lectures in big auditoria seem to be history. The German poet Wilhelm Busch (1832-1908) once wrote: 'Wenn alle schlafen und einer spricht, diesen zustand nennt mann unterricht" (When all sleep and one speaks, this situation is considered to be education). And indeed there is ample evidence that many students do not learn during mass lectures.

Another argument to actively engage with students is that the lecturer can benefit from the different, possibly international, diverse backgrounds of students. If students contribute from their perspective or cultural background, discussions/interactions in class become richer. So if in a class on 'corporate governance' students from North America or Asia can tell about their home situations and mingle with Europeans the quality of the course 
will increase. This is the main argument of the International Classroom: making all students feel included and activate them in class by bringing in their own cases and experiences. In the International Classroom diversity is an asset instead of a liability.

Another argument for 'active learning' is that the student learns more (or at least remembers better the experiences in the course) and it is more fun. Students moreover come to the 'richer' domains of learning, as proposed by Bloom et al. (1956). The Bloom Taxonomy of learning domains refers:

1. Remember: recall facts and basic concepts;

2. Understand: Explain ideas or concepts;

3. Apply: use information in new situations;

4. Analyse: Draw connections among ideas;

5. Evaluate: Justify a stand or decision;

6. Create: Produce new or original work.

The hope is that we can push students from the basic phase of remembering to the creative domain as soon as possible. The probability to move up along Bloom's taxonomy is larger if students become more active. It is also likely that students become more entrepreneurial as soon as more activity is required.

The probability that students will become more interested also increases if real-life problems are used in the classroom. In the International Classroom this implies that international real-life cases will trigger more attention than theoretical cases. The main advantage of a real-life case is that there is more clarity about the end solution of the issue and the student is forced to think about making assumptions and the choice of the solution methods. In order to complete this argument: in theoretical problems it is precisely the other way round: we know the problem, we 
know the algorithm to be applied and the outcome in the single unknown issue.

Working with real-life problems and moving up Bloom's taxonomy also contributes to the increasing issue of employability concerns. Students nowadays are more concerned about their future career options than decades ago. Labor market volatility has increase (job duration is shorter) and the probability that an alumnus will serve for the same institution or firm for lifetime is really low. Students like to prepare better for this uncertain future and a very good way to prepare is to gain experience in solving real-life problems.

On the way, we are lucky that ICT has improved. It has improved so much in education that we have ample tools to support active learning. We have many tools that prepare students before class starts: the so-called Flipped Classroom setting. We have better tools that students can use in communication. We have better tools for students to interact (classroom voting). We have better tools to assess the quality of students. We have better tools to give students easy access to all information sources.

\subsection{Assessment}

One element in this discussion is the attention for assessment of the quality of students. Harvard Professor Eric Mazur calls assessment "the silent killer of education". Students are rational: the study along the prescriptions of assessment. The way assessment is organized is basically the line of learning by students. There are various issues relevant here:

1. Students are rational and apply just-in-time management. In Kindergarten we start training children to behave 
'just-in-time': prepare shortly before the event. This implies if remembering is the largest fraction of required competencies, students will prepare just-in-time even more. There is a lot of evidence that people in the age of about $20-25$ can remember quite easily about $80-85 \%$ of the material for about 3 days;

2. Most assessment procedures imply an ex-post test: there is no feedback of the test on learning;

3. In most cases students are tested in isolation: no connection to the Internet, no textbooks and certainly no contact to fellow students;

4. Most examinations give feedback in one dimension: a single grade;

5. Most assessment forms focus on the 'lower' goals of Bloom's taxonomy.

Linking these observations to the discussion on the adaptation of the International Classroom one can make the observation that classical assessment is not to the benefit of 'inclusion and activation'. From a Flipped Classroom perspective a single assessment ex post is undesired. It is by far better to do a pretest before class starts: the lecturer than knows where deficiencies possibly are and can cope with it during class. In the Flipped Classroom continuous feedback is a necessity. Feedback could also be given better in line with the pre-set learning outcomes. A student can do great on presenting, but needs some improvement on academic contents or the other way round.

Peer group instruction and assessment also fit better into the International Classroom setting than stand-alone 'isolated' learning and assessment. It is pretty unlikely that an alumnus will have to work in full isolation, without Internet connection, without any form of contact with colleagues. Moreover, for 
international students it is great to have the interaction with fellow students. Peer group instruction can also use a free and more creative setting: solving real-life problems in a group leads to intensive discussions and interactions, which will be memorized better than simply collecting facts.

Summarizing, phase 3.0 of internationalization will focus on the adjustment of the education at home. Two keywords are relevant: inclusion and activation. Inclusion applies to all students (home-based and international): the university opens its facilities and makes all students feel at home. Next it is activation. More active students learn more and have more fun. Activation of students needs adjustment of the organisation of education: the Flipped Classroom and ICT help. Activation also correlates with a stronger focus on creativity. Finally, the diversity of the student population in class must be considered to be an asset and should be used by the lecturer.

\section{Concluding remarks}

In this chapter I describe the opportunities for internationalization in Europe. I first gave a short review of the origin and some of the concerns of the Bologna Declaration. Internationalization is nowadays concerned with spreading the reputation of universities and adjusting education to the needs of all, home-based and foreign, students. I described a next step in internationalization of campus universities: the model of inclusion and activation. Inclusion applies to the openness of campus universities to all students in terms of language and culture. Activation implies to the learning and teaching methods applied on campus. The Bologna Declaration has set the scene: now universities should try to improve their campus policies. They should try to open up their institutions a bit 
better to all international students and they should try to activate students in class, letting them to bring in their own experiences, and use the diversity of the student population in class. Inclusion of all students is instrumental and a necessary step in order to be able to activate them in class. Active forms of learning are known to be successful. Moreover, it is more fun for students.

Changing universities is typically hard. Universities exist for a thousand years in Europe and basically they do the same as centuries ago: combining research and education is a smart way. A radical change is therefore very unlikely. The emeritus professor of the University of Edinburg Geoffrey Boulton (2009, p. 69) has once commented: "Changing a university is like moving a graveyard; you don't get much help from the people inside". In a professional organization administrators can only try to convince staff members to consider a change instead of forcing them into a new educational strategy. Still university managers should do two things. First, talk to their political leaders to strongly support European collaboration. And secondly, they should try to offset all day-to-day disturbances of 'Bologna'- difficulties within their institutions. Next they should work on the 'inclusion and activation'. It is all to the benefit of next generations of academics. We should all focus on: Making Bologna really Work! Maybe in one day the European crowd will cheer again to academic processions, like in 1614 in Groningen.

\section{References}

Bloom, B.S., Engelhart, M.D., Furst, E.J., Hill, W.H.; Krathwohl, D.R. (1956). Taxonomy of educational objectives: The classification of educational goals. Handbook I: Cognitive domain. New York: David McKay Company. Boulton, G. (2009). Global: What are universities for? University World News, 29 March. 